\title{
DIE PARTYPOLITIEK EN DIE TOEKOMS VAN DIE AFRIKAANSE VOLKSKULTUUR
}

Reeds in 1853 het die Zuid Afrikaan hom soos volg uitgelaat:

„Dis 'n dwaling wat ons reeds meermale bestry het dat ons as Britse onderdane verplig sou wees, om die Britse nasionaliteit ons s'n te maak. Die Kolonis van Hollandse oorsprong kan geen Engelsman word nie, en moet ook geen Nederlander wil wees nie. Wanneer hy weet om sy standpunt te waardeer, dan sal hy as verligte kolonis die grondtrekke van die Engelse volkskarakter met dié van die Nederlandse harmonies leer verenig en daardeur word wat hy as Kapenaar moet word."

Die rede waarom ek dit aanhaal, is nie om aan te dui hoe oud die woord "verlig" is nie, maar om te wys op die stryd wat die Afrikaner oor so 'n lang periode teen 'n sterk en mededingende kultuur moes voer.

Ek wil daardeur ook wys op 'n weifeling by sommige aangaande die voortbestaan van die Afrikanervolk as volksen kultuurgemeenskap op 'n stadium toe die Afrikaanse volkskultuur lank reeds sy beslag gekry het, in die Boererepublieke binne eie staatkundige verband gedy het, maar juis vandaar 'n terugwerkende seën na die weifelaars versprei het.

Veral gedurende die $19 \mathrm{e}$ eeu het ons 'n worsteling soms uiters dramaties - aanskou tussen die Afrikaanse volkskultuur en die Britse taal, kultuur en lewenshouding.

'n Deel van daardie drama loop deur die Groot Trek, die ontworsteling aan die greep van Britse oorheersing, die taalbeweging, die twee Vryheidsoorloë, die stigting en prestasies van die Nasionale Party as die Afrikaner se politieke volksfront wat sou stry vir gelykberegtiging van die Afrikaner, voorts die stigting van kultuurverenigings en verder die hele ontplooiing van wat as die Afrikaanse nasionale beweging bekend staan.

Hierdie nasionale beweging is treffend beskryf as „die totale, omvattende volksaksie van die Afrikaner om homself as nasie te laat geld, om ooreenkomstig eie volksaard te lewe en te ontwikkel, om toestande of verskynsels wat sy 
selfverwesenliking as nasie bedreig of in die wiele ry, die hoof te bied, en om op elke gebied van die lewe - maatskaplik, godsdienstig, kultureel, wetenskaplik, opvoedkundig, ekonomies, politiek - volwaardig te wees, as gelykwaardige sy plek naas ander in te neem en op gelyke voet met ander sy rol te speel en sy bydrae te lewer (prof. G. Cronjé, Akademie-jaarboek 1963).

Die implikasies hiervan, soos dit veral die verhouding Afrikaanse volkskultuur en Engelse kultuur betref, het op die volgende neergekom:

a) Die weerstand van Afrikaanse kant teen die Engelse taal, kultuur, en lewensbeskouing was 'n weerstand daarteen o.a. as draer van die Britse imperiale verband.

In die maatskaplike, ekonomiese, politieke en selfs kerklike lewe is pogings aangewend om die Afrikaner te angliseer en sy taal, kultuur en lewenshouding stelselmatig te verdring.

b) Daar was wel in Afrikanergeledere 'n soort gespletenheid deurdat 'n groot deel daarvan kultureel en selfs kerklik vervreem het en polities diensbaar geword het aan die imperialistiese gees en strewe. Hierdie gespletenheid was 'n ernstige slag vir die Afrikaanse volkskultuur.

Ons het veel aan krag ingeboet.

Dit het 'n eenstemmige bevordering van die Afrikaanse kultuur belemmer: dit het die Afrikanervolk verdeel en dit het hom polities lank onmondig gehou.

c) Daar het egter in Afrikanergeledere plaasgevind wat ons die re-kulturasie van verloregaande Afrikaners kan noem, deurdat ' $n$ besondere dinamiek in Afrikanergeledere geopenbaar is in die weerstand teen die imperialistiese Engelse kultuur van die $19 \mathrm{e}$ eeu, asook deurdat die lewenskragtigheid van die Afrikaner se kultuur hom op selfverwesenliking gerig het en kenlike vrug gedra het.

Deur die Eerste en Tweede Taalbeweging sou Afrikaans as uitdrukkingsmiddel vir die eie gedagte en kulturele en politieke strewe gesmee word.

Deur moedertaalonderwys is in eie kultuurbewustheid by die Afrikanervolk se jeug ingeskerp en is sy eie lewenshouding verwoord en oorgedra.

Op die gebied van die universiteitswese het die Afrikaanse volksaksie beslag gekry en is aan Afrikaanse universiteite 
leiers vir verskillende terreine gekweek, en veral manne en vroue wat in die bevordering van die Afrikaanse kultuur 'n besondere rol gespeel het.

d) Die Afrikaanse nasionale beweging, in mededinging met die vroeëre imperialistiese inslag van die Engelse kultuur en lewenshouding, het egter ook meegebring dat die Afrikanervolk vir homself rekenskap moes gee van sy ekonomiese krag of sy aandeel in die landsekonomie.

Ons het besef dat ons volkskultuur ook ekonomies verankerd is. Of anders, die besef het deurgedring dat die Afrikaner se kultuur ook te vind is in sy aktiwiteite (as Afrikaner) op die gebied van die ekonomie.

Juis daarom het ons geworstel met die Armblankevraagstuk. Daarom is Afrikaanse organisasies vir maatskaplike sorg in die lewe geroep.

En daaraan is toe te skrywe die opkoms van Afrikaanse handelsinstellings, sake-ondernemings, finansiële- en nywerheidsinstellings.

Dit is deel van die Afrikaanse volkskultuur.

e) Dieselfde het gebeur op die gebied van die onderwys en opvoeding. As die Afrikaner nie weerstand gebied het teen sy anglisering langs die weg van die onderwys nie, was dit lankal ikabod met 'n Afrikaanse volkskultuur.

As hy nie gestry het vir moedertaalonderrig nie, was dit lank reeds soos iemand in Di Patriot in 1881 gesê het:

"die einde van die toekoms van ons nasie"!

\section{Politieke volksaksie}

Dit bly egter ondenkbaar dat die Afrikaanse volkskultuur in sy aksie sou halt roep vóór die politieke volksaksie, of daarsonder volwaardig sou wees.

„Die wesenlike eienskap van alle volke waardeur hulle onderskei word van ander mensegroepe, is 'n drang na vergestalting in 'n eie staat, om vry te wees van vreemde heerskappy" (dr. J. Albert Coetzee: Nasieskap en Politieke Groepering, bl. 5).

En dit is wat ook in Suid-Afrika gebeur het. Die Afrikaner as volks- en kultuurgemeenskap is polities baie lank miskien in die land van sy geboorte, sy vaderland.

Ook deur die aanwending van politieke mag, gerugsteun 
deur militêre mag, is die vrye ontplooiing van die Afrikaner se kultuur teëgegaan. Die berusting in permanente onderhorigheid was egter ondenkbaar. Dis ondenkbaar dat 'n volksgemeenskap wat hom voortplant met eie groepsbewussyn, gewoontes en tradisies, waardering vir sy deurleefde geskiedenis, taal en in hoë mate godsdienstige band, die politieke beheer en selfbeskikking sou geringskat.

Dit sou op 'n onmondigheid of selfs 'n onhoudbare gespletenheid by die volk dui.

Die Afrikaanse nasionale beweging was dan ook juis 'n aaneenlopende volksaksie oor die hele linie heen en dit het die politiek ingesluit.

Teen hierdie agtergrond verstaan ons die verloop van ons volk se politieke geskiedenis beter.

Ek dink die rede waarom die Afrikaner in Kaapland gedurende die tweede helfte van die $19 \mathrm{e}$ eeu eintlik in 'n sekere mate polities oneffektief was, moet nie net toegeskrywe word aan sy weifeling in sy verhouding tot die Engelse taal, kultuur en lewenshouding nie. Dit is m.i. ook te wyte aan 'n gebrek in sy politieke siening. Die Afrikaner was polities ingeskakel in 'n Britsbeheerde politieke patroon. Van Afrikaner selfbeskikking was daar nie sprake nie.

In 1892 kon „Onze Jan” bv. nog verklaar: „The English colonist, and the Dutch colonist, he believed, were equally faithful in their allegiance to the Crown".

Die jare ná die tweede Vryheidsoorlog het die politieke leiers laat worstel met die probleem van die volk as kultuurgemeenskap en die ideaal van konsiliasie. Reeds in 1903 het genl. Botha op Heidelberg die „volk” gesien as almal wat die land "as hul tuiste kies en waarlik die vooruitgang en voorspoed daarvan op die hart dra".

Daarteenoor het genl. De Wet verklaar: „Wee hom wat die verlede nie voor oë hou nie. Die Afrikaanse volk word opgebou op sy geskiedenis".

Die Solomons (E. P. en Harry) was bereid om met die Boere saam te werk ,as long as they respected and recognised the supremacy of Great Britain".

Genl. Smuts verklaar op die Het Volk-kongres in 1905: „Vir my is dit duidelik dat God ons deur die geskiedenis wou toon dat ons verkeerd was. As ons met die nuwe bevolking nie een volk kan word nie, dan is daar geen kans vir 
ons en ook nie vir hulle nie".

Sy onderwyswet van 1907 het Engels eintlik nommer een gestel en die Hollandse taal is 'n minderwaardige posisie toegeken.

Genl. Botha versoek Reuter (in Engeland) in 1907 selis om mee te deel dat hy nie graag die nuusblaaie lees wanneer hulle onderskeid maak tussen Afrikaners en Engelse in SuidAfrika nie.

Ook was hy daarvoor om hierdie "Suid-Afrikane" te vermeerder deur immigrasie uit Engeland "in groot getalle".

Hier was dus 'n politiek in aksie wat die Afrikaanse volkskultuur wou offer op die altaar van konsiliasie onder die Britse vlag en heerskappy. Wat Paul Kruger genoem het die "wortel van ons volkshistorie", sou hierdeur afgesny word.

\section{Samesmelting}

By die stigting van die Zuid-Afrikaanse Party verklaar genl. Botha op 21 November 1911 dat die ernstige gees van toenadering en verdraagsaamheid onder albei seksies van die Suid-Afrikaners meedoënloos „alles wat in die weg kom van toenadering en samesmelting van die twee blanke seksies" uit die weg sal slinger, want uit die samesmelting word 'n ,jong veelbelowende nasie gebore".

Daar moenie net van samewerking met die oog op politieke voordele gepraat word nie, maar „dit is duidelik soos die dag dat die Voorsieningheid wil dat ons een volk sal vorm".

Genl. Botha verwys dan spesifiek na die onaanneemlike alternatief wat hy die weg van isolasie tussen die blanke rasse noem. Dis diegene wat „dink dat daarlangs hul taal en tradisies beter in die lewe gehou sal word. Ek sien geen heil vir hierdie weg nie, want daardeur sal Suid-Afrika 'n huis teen homself verdeel wees en bly, met 'n gewisse val voor hom".

Dit was te begryp dat politici die formule wou vind waarvolgens Boer en Brit, wat kort tevore nog onder die wapen teen mekaar gestaan het, in een politieke bestel versoen sou word.

Die Afrikanervolk het hom egter in meer as een opsig 
deur die politieke formule van generaals Botha en Smuts bedreig gevoel: die Afrikaner-volksgees, die Afrikaanse taal en leefwyse het daardeur in die gedrang gekom. Dié situasie het dus geroep na 'n persoon wat in die politieke arena die saak van die Afrikaner as volks- en kultuurgemeenskap sou opneem. Daardie man was generaal Hertzog.

In teenstelling met generaals Botha en Smuts se ideaal van ,'n verenigde nasie", met prysgewing van die „bestaande" en verwerping van die Afrikanervolksverlede as "verkeerd", was generaal Hertzog se verwysing na die volk 'n verwysing na die Afrikanervolk, die Afrikanerdom.

Die volk was vir hom nie soos vir sy eertydse twee strydmakkers, 'n volk van "Suid-Afrikane" nie, maar 'n volk van „Afrikaners" met hul eie taal - ons kan sê die draers van 'n eie volkskultuur.

Soos hy reeds op 10 November 1905 op Wepener gesê het: „Elkeen wat gewillig is om sy lot in te werp met die Hollandssprekende element en aan Suid-Afrikaanse belange die eerste plek gee, behoort staanplek by ons te hê". Maar hier was die Afrikanervolk ten volle gehandhaaf.

En toe die Nasionale Party gestig word, kry ons in sy Program van Beginsels die erkenning van ,die leiding van God in die lotgevalle ook van lande en volkere". Dit "soek die ontwikkeling van die volkslewe langs nasionale weg".

Wat die „eenheid van die Europese bevolking” betref, dit "moet gesoek word deur op manlike wyse daarop aan te dring dat elke deel van die bevolking tot sy regte kom".

In die „Toeligting" word later verduidelik: „Die leer van die Nasionale Party verg geen eensydige opoffering van taal of geskiedenis of van enige ander reg of belang van welke syde ook. Juis die teenoorgestelde... Ons moet één volk wees, maar die eenheid hoef nie meer as ' $n$ maatskaplike en geestelike eenheid te wees nie, met volle behoud van ons wedersydse volksrykdomme, bestaande uit taal, geskiedenis, godsdiens, gewoontes en sedes".

Dis opvallend hoe hierdie uitdrukkings soos 'n goue draad deur die partypolitieke geskiedenis van die afgelope vyftig jaar loop.

In 1915 kon dr. D. F. Malan met krag verklaar: „Vra die volk om hom in 'n ander bestaande of nog nie bestaande volk te verloor, en hy sal antwoord: om die ere Gods, 
beslis nee!"

Jare daarna, in November 1939, het generaal Smuts nog weer van die "een nasie in een land" as die ware en regte pad van Suid-Afrika gepraat.

In 1942 word die eerste mosie vir die stigting van 'n Republiek deur dr. Malan voorgestel en sê hy onder andere: „dat dit Christelik-nasionaal moet wees in wese en karakter en gegrond moet wees op die getroue inagneming van die gelyke taal- en kultuurregte van albei seksies van die blanke bevolking!"

En so kan die lyn deurgetrek word tot by die jongste partypolitieke uitsprake oor die Afrikaanse volkskultuur.

Toe sedert Republiekwording groot nadruk gelê is op die breë nasionale eenheid en die gemeenskaplike trou aan die Republiek, is daar hier en daar die indruk geskep asof die Afrikaner as onderskeibare volks- en kultuurgroep in die gedrang gekom het.

Die beëindiging van 'n dubbele burgerskap of lojaliteit aan 'n vreemde land ten koste van Suid-Afrika, het by sommige visioene van volksbou laat ontstaan wat niks verskil van die samesmeltingsoogmerke aan die begin van hierdie eeu en later nie.

Dr. Verwoerd het in 1964 hierop gereageer in 'n skrywe aan Pretoriase studente: „So 'n kleurlose samevoeging (sou) nie aanneemlik wees nie vir of die standvastige Afrikaner of die Engelssprekende Suid-Afrikaner nie. 'n Mens verwag te veel as jy binne enkele jare twee aparte volksbestanddele so geheel en al in mekaar wil laat opgaan. Die vorming van 'n nuwe nasie in daardie volle sin, soos met die Engelse uit die Saksers en Normandiërs gebeur het, neem eeue eerder as dekades".

Maar veral ons huidige Eerste Minister, adv. Vorster, het die saak baie duidelik gestel toe hy nie net na Afrikanereenheid as „kosbare kleinood" verwys het nie, maar verklaar het dat ons in Suid-Afrika 'n Afrikaanse volk bou met eie taal, kultuur, sedes, tradisies, gewoontes en daarnaas 'n Engelssprekende kultuurgroep met sy eie taal, kultuur ens.

Hy het bygevoeg: „As die Afrikaner en die Afrikanerdom sou ondergaan, sal dit 'n onherroeplike ramp vir Suid-Afrika wees".

Dit is uitsprake wat gelê moet word langs die wat pleit 
vir 'n gevoel van eenheid tussen die taalgroepe.

Omdat die een taal- en kultuurgroep nie meer 'n verlengstuk is van ' $n$ ander tuisland nie; omdat sowel Afrikaner as Engelssprekende inheems is of in toenemende mate word, lê dit voor die hand dat die afgrensing tussen die twee nie deur verdelende faktore soos die Vryheidsoorloë ingegraveer sal word nie.

Ons kan sê dat in ons partypolitiek - Regeringsparty of Opposisie - daar afgestuur word op die groots moontlike samewerking en eenheid van die twee kultuurgroepe.

Wat die Nasionale Party betref, het hy hom ferm op die behoud van identiteit geplaas.

Dit sal seker nie verkeerd wees om te beweer dat dit sedert die stigting van die Party hom in eerste instansie in die praktyk te doen was om gelykberegtiging van die Afrikaner nie.

Die Afrikaner se politieke stryd en sy kulturele stryd was intiem verweef. Hy het besef dat die handhawing en uitbouing van die Afrikaanse volkskultuur nie kon halt roep voordat hy ook politieke mag verower het nie. En hy het verder besef dat terwyl die verkryging van politieke mag in die breë sin van die woord deel is van die volkskultuur, die aanwending van die politieke mag nodig geword het om die volkskultuur teen ondermyning en diskriminasie te beskerm.

Maar nou het ons tog hierdie interessante situasie soos ek dit sien. Dic politieke party is geen uitsluitend Afrikanerparty nie en wil dit ook nie wees nie. Hy onderskryf politieke beginsels wat ook deur Engelssprekendes aanvaar word.

Binne die Party wat homself „die politieke volksfront van die Afrikanerdom" noem, is daar nie-Afrikaners wat die politieke nasionalisme van die Afrikaner deel.

Hulle was van die begin af welkom daar. Generaal Hertzog het aan hulle 'n "staanplek by ons" toegeken - aan dié wat hul lot met die Hollandssprekende element inwerp.

Dit moet gesien word teen die agtergrond van die verkleefdheid van baie Engelssprekendes aan Groot-Brittanje in plaas van inheems Suid-Afrikaans te word. Hulle moes eers Suid-Afrika Eerste aanvaar benewens ander punte van politieke beleid. 
Ek sien die posisie vorentoe soos volg:

1. Die spanning tussen 'n Afrikaanse volkskultuur en 'n Brits-imperialistiese kultuur en lewenshouding is verby. Die Engelse kultuurgroep in Suid-Afrika is besig om te besin oor hul eie identiteit en die patroon van samewerking met die Afrikaner.

2. Namate die getal Engelssprekendes polities die standpunt van die Afrikaner aanvaar en dus saam met hom in een politieke party optree, spreek dit vanself dat die politieke party se bemoeienis met die engere kultuurlewe van die Afrikaner, soos dit ook op bepaalde vlakke in mededinging met die Engelse kultuur is, nie so partydig kan wees dat dit uitsluitend tipies Afrikaanse kultuurbelange aktief kan bevorder nie.

3. Dit wil nie sê dat hy onverskillig sal staan teenoor Afrikanerbelange nie, maar 'n aktiewe kampvegter en aksiefront van die Afrikanervolkskultuur kan hy uit die aard van die saak nie ongekwalifiseerd wees nie.

4. Dit is egter die stellige standpunt dat daar nie uit die politiek pogings aangewend sal word om 'n soort kulturele samesmelting te bevorder wat dan lastige probleme binne die party sou kon onderskep nie. Daarvoor is die versekeringe oor die behoud van Afrikanereenheid en identiteit te sterk om misverstaan te word.

5. Dit spreek ook vanself dat waar die voortbestaan van die Afrikaanse volkskultuur ons erns is, ons ook in ons immigrasiebeleid realisties en versigtig sal wees. Van verskeie kante uit partypolitieke kring is daarop gewys hoe kosbaar ons kulturele waardes, ons volksbestaan is en dat die ekonomiese - wat ook binne die bestek van ons kultuurtaak val - nie buite verhouding tot ander fasette van ons volkskultuur beklemtoon moet word nie.

6. Treffend het prof. W. J. du P. Erlank by die Derde Eeufees gewaarsku: „dat geen volk 'n onbepaalde industriële uitbreiding durf toelaat, wat hy kultureel en sosiologies nie kan verwerk nie".

En hierdie dinge lê verweef ook in ons politieke beleid van nywerheidsvestiging en uitbreiding, die werwing van mannekrag in die buiteland of ook die sametrekking van groot getalle nie-blankes in ons stede.

7. Terwyl, soos ek probeer aantoon het, die partypolitiek 
nie langs kultureelhomogene bane gevoer word nie, en die Afrikaanse volkskultuur desnietemin vir ons die grootste erns is, lyk dit voor die hand liggend dat die Afrikaner in die toekoms in 'n nog groter mate aangewys sal wees op sy eie kultuurorganisasies en -funksies.

Binne die een politieke bestel is daar ruimte vir 'n meervoudigheid van belange ten opsigte waarvan die owerheid as trustee optree in die sin dat hy die belange daarvan moet beskerm teen onewewigtige geldendmaking van die belange van ander.

Deur die Afrikaner se kultuurgeledinge sal hy nie alleen sy belange organiseer en teenoor die owerheid waar nodig voordra nie, maar sal hy ook sorgdra dat sy politieke verteenwoordiging nie tot sy skade oor die hele kulturele linie heen verwaarloos word nie.

Hoe dit in presiese ewewig met die omvattende belange van ander kultuurgroepe in dieselfde politieke bestel gedoen word, is 'n saak wat groot wysheid vorentoe sal verg.

Pretoria.

A. P. Treurnicht. 